University of California

Division of Agriculture and Natural Resources

http://anrcatalog.ucdavis.edu

\title{
Native and Naturalized Plants for the Home Garden in Northern California
}

DAVA CASTILLO, former UC Master Gardener; RACHEL ELKINS, Pomology Farm Advisor, University of California Cooperative Extension, Lake County

\section{WHAT IS A NATIVE PLANT?}

Native or indigenous plants are defined as plants, shrubs, and trees that naturally occur in the region, area, or biome in which they originally evolved. These plants have coevolved with wildlife, fungi, and microbes to form mutually dependent relationships that are the foundation of our native ecosystems. Some plants might be introduced from another area and then become established, a process known as naturalization. Sometime the naturalization of a plant in an area can be a good thing or a bad thing, depending on the characteristics of that particular plant. Aliens plant may come to be looked upon as a nuisance if they are tenacious enough to spread without human assistance and may even survive attempts to eradicate them. Whether native or naturalized, these plants have adapted to the general climate, microclimate, altitude, soil, and rainfall of a particular area.

\section{WHAT ARE THE BENEFITS OF USING NATIVE PLANTS?}

- Most native plants have developed natural defenses to local diseases and insects, minimizing requirements for pesticides. Since many commonly used pesticides kill relatively indiscriminately, beneficial insects become secondary targets in the fight against pests. Reducing or eliminating pesticide use lets natural pest control take over and helps to keep toxins out of our waterways.

- Once established, many California native plants need minimal irrigation beyond normal rainfall. Saving water conserves a vital, limited resource and saves money, too.

- Wildlife species use native plant communities as their natural habitat. California's wealth of insect pollinators can improve fruit set in your garden, while a variety of native insects and birds can reduce populations of mosquitoes and plant-eating bugs. By using native plants you can help preserve the balance of natural ecosystems. 


\section{HOW DO WE KNOW WHICH PLANTS ARE NATIVE?}

Botanical studies of the world's flora have been ongoing for many years, and they have included many specimens and historical drawings of new world plants that where brought to America by European explorers. Additionally, paleobotanists have been able to compare fossil records with modern plants to identify which plants are native to an area.

\section{ARE NON-NATIVE PLANTS HARMFUL?}

Many non-native plants are harmless or even valuable, but others can take over natural communities and eliminate native plants. They are able to do this because the natural diseases, pests, foraging animals, and weather conditions that kept them in check in their native homelands are absent here. Many non-native plants are classified as weeds or invasive plants. Many weeds belong to the daisy, pea, and grass families. Jubata, pampas grass, broom, and Cape ivy are prominent examples of well-known invasive plants that can deprive our wild life of food and shelter.

\section{NATIVE VERSUS NATURALISTIC PLANTING}

"Naturalistic" has been defined as "imitating or producing the effect or appearance of nature," referring to the arrangement and selection of plants indigenous to a specific area. Naturalistic plantings can be characterized by groupings and forms that reflect how plants would grow in an undisturbed environment. However, there is a misconception that landscapes using native plants should look like a natural woodland or prairie, which may be perceived by some as being unkempt or not maintained. Native plants may be used just as any other ornamental garden plant and may be incorporated into existing garden types. How native plants are physically arranged in the garden usually does not impact their ecological value.

\section{HOW DO I START A NATIVE GARDEN?}

\section{Survey Your Site}

What are the growing conditions?

- The habitat might be forest, serpentine, woodland, lakeshore, meadow, slopes, understory, or river bank, to name a few.

- Specific site conditions include sun, shade, and water availability and source.

\section{Select Your Species}

- Choose shrubs that match your site conditions for sun and moisture, allowing for minimal use of garden watering after establishment.

- Plant for spring and summer flower color and fall and winter foliage and berries; this will provide year-round interest. If children frequent your garden, choose nonpoisonous plants.

- Start with young native stock so plants acclimate to your soil and conditions as they grow to mature plants. Fill in empty areas with bark chips or other filler.

- Plant for diversity to imitate natural landscape patterns in your area.

- Pay attention to edge vegetation. Do you need lowgrowing plants? Do you need to control spreading varieties?

- Determine the mature height and width of plants, allowing room for growth. Crowded plants need more frequent pruning and care.

- Note whether plants are evergreen or deciduous for seasonal appearance.

- All young plants need water to become established. Plant new plants when the weather is not too hot (fall is best) and keep weeds down to avoid competition for water and nutrients.

\section{WHERE TO FIND NATIVE SPECIES}

It is easier and advisable to select native plants that suit your selected site than to modify the site to suit the plants. Native plants can be observed in their natural habitats in many places, including state parks, national forests, arboretums and botanical gardens, natural preserves, and specialty nurseries. Collecting wild plants without a permit is illegal on California public lands.

For more information on native species suited to your area, contact your local UC Master Gardener Program; see the Master Gardener Web site, http://www.camastergardeners.ucdavis.edu/.

Other sources include Web sites and books. Due to growing popular demand, some conventional nurseries now carry, or can order, a large selection of plants native to California. Plants can also be purchased through

- California Native Plants Society (CNPS) chapter plant sales(for links to local chapters, see www.cnps.org)

- arboretums and botanic gardens

- mail-order native plant nurseries listed in books and on the Internet (e.g., www.cnps.org) 


\section{ACKNOWLEDGMENTS}

The authors wish to thank Carolyn Shaffer for assisting with publication revision and formatting.

\section{FOR FURTHER INFORMATION}

California Native Plant Society Web site homepage, http://cnps.org/cnps/nativeplants, accessed January 23, 2009.

. Why garden with native plants Web site, http://www.cnps.org/cnps/grownative/why_native. php\#brochure, accessed September 10, 2009.

To order or obtain printed publications and other products, visit the ANR Communication Services online catalog at http://anrcatalog.ucdavis.edu. You can also place orders by mail, phone, or FAX, or request a printed catalog of our products from:

\section{University of California}

Agriculture and Natural Resources

Communication Services

6701 San Pablo Avenue, 2nd Floor

Oakland, California 94608-1239

Telephone: (800) 994-8849 or (510) 642-2431

FAX: (510) 643-5470

E-mail inquiries: danrcs@ucdavis.edu

(C2009 The Regents of the University of California

Agriculture and Natural Resources

All rights reserved.

No part of this publication may be reproduced, stored in a retrieval system, or transmitted, in any form or by any means, electronic, mechanical, photocopying, recording, or otherwise, without the written permission of the publisher and the authors.

\section{Publication 8401}

ISBN-13: 978-1-60107-677-9

The University of California prohibits discrimination or harassment of any person on the basis of race, color, national origin, religion, sex, gender identity, pregnancy (including childbirth, and medical conditions related to pregnancy or childbirth), physical or mental disability, medical condition (cancer-related or genetic characteristics), ancestry, marital status, age, sexual orientation, citizenship, or service in the uniformed services (as defined by the Uniformed Services Employment and Reemployment Rights Act of 1994: service in the uniformed services includes membership, application for membership, performance of service, application for service, or obligation for service in the uniformed services) in any of its programs or activities.
University policy also prohibits reprisal or retaliation against any person in any of its programs or activities for making a complaint of discrimination or sexual harassment or for using or participating in the investigation or resolution process of any such complaint.

University policy is intended to be consistent with the provisions of applicable State and Federal laws.

Inquiries regarding the University's nondiscrimination policies may be directed to the Affirmative Action/Equal Opportunity Director, University of California, Agriculture and Natural Resources, 1111 Franklin Street, $6^{\text {th }}$ Floor, Oakland, CA 94607, (510) 987-0096. For information about ordering this publication, telephone 1-800-994-8849. For assistance in downloading this publication, telephone 530-754-3927.

An electronic copy of this publication can be found at the ANR Communication Services catalog Web site, http://anrcatalog.ucdavis.edu.

\section{UCER}

REVIEWED This publication has been anonymously peer reviewed for technical accuracy by University of California scientists and other qualified professionals. This review process was managed by the ANR Associate Editor for Environmental Horticulture.

web-09/09-SB/CR 